\title{
Validity and Reliability of the Hand Eye Coordination Test Instrument Table Tennis for PJKR FIK UNY Students During the Distance Learning (PJJ) period
}

\author{
Alfonsus Maria Bandi Utama ${ }^{1, *}$ Dennis Dwi Kurniawan ${ }^{1,}$ Agus Susworo Dwi
}

\author{
Marhaendro ${ }^{1,}$ Amat Komari ${ }^{1}$
}

\author{
${ }^{I}$ Faculty of Sport Sciences, Universitas Negeri Yogyakarta, Yogyakarta, Indonesia \\ *Corresponding author.Email: bandi_utama@uny.ac.id
}

\begin{abstract}
Distance learning in the field of sports education has great challenges during the implementation of practical learning. In the table tennis course, it is necessary to identify the initial ability of hand-eye coordination of PJKR FIK UNY students through special test instruments for the sport of table tennis. The purpose of this research is to make it easier for students to carry out distance learning and self-practice test assessments to identify hand-eye coordination skills specifically for table tennis, which so far have no instruments. The application of this test instrument includes research on the development of a table tennis game eye-hand coordination test instrument that uses content validity and reliability tests. The sample consisted of table tennis students from PJKR FIK UNY which was taken by all students from two classes, namely 100 students. The results of the validity test using aiken's $\mathrm{v}$ with a content validity result of 0.883 which is declared very valid. The results of the reliability test with the test-retest method got the results of the instrument reliability of 0.89 so that the instrument was declared very reliable. The conclusion is that the instrument developed is feasible to be used as a measuring tool for specific eye-hand coordination in the branch of the table tennis game and the application of test guidelines using audio-visual media can improve the results of the eye-hand coordination test in PJKR FIK UNY student
\end{abstract}

Keywords: Distance Learning, Eye-Hand Coordination, Practice Test Instruments, Table Tennis Games

\section{INTRODUCTION}

In the modern era in the 21 st century, distance learning has become an effective way and according to the latest needs according to the education system [1]. Besides, learning during the pandemic really prioritizes using online learning methods. During the online (online) or distance learning (PJJ)-based learning period, innovations are needed that can improve optimal learning outcomes independently. However, there are several weaknesses and many students complain about distance learning, especially in field practice learning which is considered ineffective [2]. The learning process in sports is categorized as low, the perception of students as much as $68 \%$ feels bored and $32 \%$ feels not bored [3]. The difficulty of adapting in distance learning with online methods is indeed a problem that must be given the best solution, especially in practical learning [4], one of which is in the table tennis game course in the
PJKR FIK UNY Study Program. From various previous research problems that have similar problems to the conditions of lectures at the PJKR FIK UNY Study Program, the table tennis subject is focused on the difficulties of students in carrying out practical learning because there is no clear and easy to understand rubric independently, this is a result of the lack of teacher innovation in teaching and learning. this distance learning period in order to facilitate students in the implementation of lectures.

In addition to the weakness of distance learning in field practice, table tennis also has sports characteristics that cannot be compared with other types of sports, so that in the learning approach, assessment and identification of abilities at the beginning of learning also has its own characteristics [5]. One of the advantages of playing table tennis [6] that state about the popularity of the table tennis game, namely ping pong (table tennis) is one of the various 
sports games that are easy, inexpensive, and recreational and are favored by people in the world. This is evident in the field of sports education as well, where the choice of table tennis game courses is chosen by more than $50 \%$ of the 2019 batch of students in the PJKR FIK UNY major and is divided into 2 classes. Table tennis is a game or type of sport that focuses on the ability of the eyes and hands. The specifications of the table tennis game are in the arm skills and the ability of the sense of sight, although not the only aspect, table tennis draws significantly on the coordination ability or motor skills of the players [7],[8].

However, in the table tennis game itself, there is no special eye-hand coordination test instrument for the table tennis game, because so far the eye-hand coordination has only used the common type of handthrowing test, so it is not in accordance with the characteristics of the needs of the table tennis game itself. The importance of identifying abilities according to the main biomotor components of each sport, namely to determine the initial ability limit for an evaluation of an activity or exercise program to improve the weaknesses that have been detected, this also applies to the game of table tennis [9],[10],[11]. Higher motor skills had better results and forehand topspin accuracy between those who participated in mass training and distributed training also had significantly different results with those who had higher and lower hand-eye coordination [12].

Based on the specific needs of the table tennis game, it is possible to identify specific hand eye coordination abilities, and the implementation of the test can also be carried out independently by students. So the researcher assumes that it is necessary to develop an eye-hand coordination test instrument specifically for the game of table tennis for PJKR FIK UNY students during distance learning. The purpose of this development research is to make it easier for PJKR FIK UNY students to be able to identify the basic skills of playing table tennis on the eye-hand coordination component specifically in the game of table tennis and the test can be done independently during distance learning.

\section{METHODS}

The population of the participants in this development research were students of PJKR FIK UNY class of 2019 who took tennis game courses in the even semester of the 2020/2021 academic year. The number of students who took the table tennis game course was 100 students who were divided into 2 classes, because the table tennis game course at the PJKR FIK UNY Study Program was an optional course in net games. The number in the gender category is 65 male students and 35 female students.
This development research was carried out following the student's learning schedule during the even semester, students took part in this research process using an online method, so the researchers tried to always provide explanations with a material approach that was easily understood by students. For the flow of the test, there are test guidelines, both written and audio-visual. In this development research, the ADDIE model that the researcher uses as an effective method, there are five stages in this ADDIE model, which consist of analysis, design, development, implementation and evaluation.

\section{RESULTS}

Based on the thematic analysis, four game media products were produced as physical education learning materials for physical fitness for children with special needs, as follows: (1) a draft of a running train game model, (2) a draft of wood saw game model, (3) a draft of a tire pumping game model, and (4) the draft model of the waving palm tree game.

Indicators used by Experts in assessing the instruments on the draft model of the running train game material, the draft of the wood saw game material model, the tire pumping game material model draft, the waving palm tree game material model draft, are as follows: (1) suitability of the game material with learning objectives, (2) suitability of game material with basic competencies, (3) clarity of game rules, (4) clarity of language and images. The results of the assessment were analyzed using the Aiken formula, which results on the data presented in Table 1 , Table 2

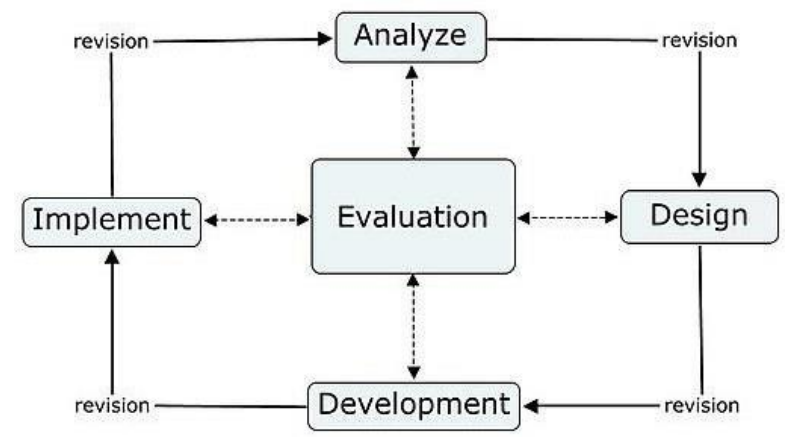

Figure 1. Research Flow of ADDIE model development.

The sampling technique used purposive sampling method. This sampling technique is specifically for students of the table tennis game course which is held in semester 4, students who choose this course are expected to have small ball playing skills, especially table tennis games. The sample chosen was 40 students to be able to represent the population, consisting of $20 \mathrm{PA}$ and $20 \mathrm{PI}$. The instruments used 
in this study were in the form of test instrument validation formats, reliability formats, interview guidelines or Forum Group Discussions in making practical test instruments (experts, lecturers, and students).

Using mixed method data analysis (qualitative and quantitative) data in the form of numbers or quantitative and strengthened by triangulation data. The content validity test used aiken's v validity analysis on 5 experts consisting of 3 table tennis experts and 2 test and measurement experts, while the reliability test used test-retest analysis.

Expert validation in this development research used 5 experts, namely 3 table tennis game experts, 2 test and measurement experts. The results of expert validation are in the form of quantitative and qualitative data, quantitative data in the form of questionnaire assessment results and qualitative data in the form of suggestions for products developed.

Table 1. Results of Analysis of All Validators in Percentage (Quantitative) has been repaired and is given an assessment sheet to assess the material components of the eye-hand coordination content specifically for the table tennis game that will be tested in the instrument. The data obtained from this expert validation is used to determine the validity of the contents of the instrument per item or component tested in a series of eye-hand coordination tests specifically for the game of table tennis. In this expert validation, using a Likert scale of 1-5 with a total of 4 variables with 23 item statements.

Table 3. Expert validation score results

\begin{tabular}{|c|c|c|c|c|c|c|}
\hline \multirow[t]{2}{*}{ No } & \multirow[t]{2}{*}{$\begin{array}{l}\text { Assessment } \\
\text { criteria }\end{array}$} & \multicolumn{5}{|c|}{$\begin{array}{c}\text { Assessment Score from } \\
\text { Expert }\end{array}$} \\
\hline & & A1 & A2 & A3 & A4 & A5 \\
\hline 1 & $\begin{array}{l}\text { Instrument } \\
\text { Variable } \\
\text { Suitability }\end{array}$ & 5 & 3 & 4 & 5 & 5 \\
\hline 2 & $\begin{array}{l}\text { Throwing } \\
\text { Technique } \\
\text { Suitability }\end{array}$ & 5 & 5 & 4 & 4 & 5 \\
\hline 3 & $\begin{array}{l}\text { Suitability of Test } \\
\text { Execution Time }\end{array}$ & 4 & 5 & 3 & 5 & 4 \\
\hline 4 & $\begin{array}{l}\text { Appropriateness } \\
\text { of Initial } \\
\text { Assessment }\end{array}$ & 5 & 5 & 5 & 4 & 4 \\
\hline 5 & $\begin{array}{l}\text { Test Guide Media } \\
\text { Suitability }\end{array}$ & 5 & 5 & 5 & 4 & 4 \\
\hline-6 & $\begin{array}{l}\text { Ease of } \\
\text { understanding test } \\
\text { criteria }\end{array}$ & 5 & 4 & 5 & 4 & 5 \\
\hline 7 & $\begin{array}{l}\text { Ease of doing an } \\
\text { assessment }\end{array}$ & 5 & 5 & 5 & 4 & 4 \\
\hline 8 & $\begin{array}{l}\text { Compatibility of } \\
\text { Distance with } \\
\text { Type of Sport }\end{array}$ & 5 & 4 & 4 & 5 & 5 \\
\hline 9 & $\begin{array}{l}\text { Easy to } \\
\text { understand } \\
\text { forehand } \\
\text { technique }\end{array}$ & 5 & 5 & 4 & 5 & 4 \\
\hline 10 & $\begin{array}{l}\text { Easy to } \\
\text { understand } \\
\text { backhand } \\
\text { technique }\end{array}$ & 5 & 5 & 4 & 4 & 5 \\
\hline 11 & $\begin{array}{l}\text { Ease of testing } \\
\text { with available } \\
\text { tools }\end{array}$ & 5 & 5 & 4 & 4 & 5 \\
\hline 12 & $\begin{array}{l}\text { Ease of } \\
\text { understanding test } \\
\text { guide media }\end{array}$ & 5 & 5 & 4 & 4 & 4 \\
\hline 13 & $\begin{array}{l}\text { Overall ease of } \\
\text { instrument }\end{array}$ & 5 & 5 & 5 & 5 & 4 \\
\hline 14 & $\begin{array}{l}\text { The suitability of } \\
\text { the opportunity } \\
\text { for }\end{array}$ & 5 & 5 & 4 & 4 & 5 \\
\hline
\end{tabular}

Table 2. Expert Suggestions and Responses to the Test Instrument (Qualitative)

\begin{tabular}{|c|c|c|}
\hline No & Expert & Feedback/ Suggestions \\
\hline 1 & \multirow{2}{*}{ A1 } & Make a written test guide \\
\hline 2 & & Add rubric filling instructions \\
\hline 3 & \multirow[t]{2}{*}{ A2 } & $\begin{array}{l}\text { Make clear picture illustrations for } \\
\text { self-test guide }\end{array}$ \\
\hline 4 & & Add throw goal criteria \\
\hline 5 & A3 & $\begin{array}{l}\text { Make an audio-visual illustration for } \\
\text { the self-test guide }\end{array}$ \\
\hline 6 & \multirow{2}{*}{ A4 } & $\begin{array}{l}\text { Create a score table in the scoring } \\
\text { rubric }\end{array}$ \\
\hline 7 & & $\begin{array}{l}\text { Give the final value norm in the } \\
\text { scoring rubric }\end{array}$ \\
\hline 8 & \multirow{2}{*}{ A5 } & $\begin{array}{l}\text { Include the legality of the test results } \\
\text { by the tester in the scoring rubric }\end{array}$ \\
\hline 9 & & $\begin{array}{l}\text { Add assessment sheets for lecturers } \\
\text { for all students }\end{array}$ \\
\hline
\end{tabular}

Before the instrument was tested on a small scale, the researchers validated 5 material experts. Each material expert is given an instrument sheet that

\begin{tabular}{ccccccc}
\hline No & Indicator & $\mathbf{A 1}$ & $\mathbf{A 2}$ & $\mathbf{A 3}$ & $\mathbf{A 4}$ & $\mathbf{A 5}$ \\
\hline $\mathbf{1}$ & Suitability & $96 \%$ & $84 \%$ & $92 \%$ & $92 \%$ & $92 \%$ \\
\hline $\mathbf{2}$ & Convenience & $100 \%$ & $87.5 \%$ & $95 \%$ & $85 \%$ & $93 \%$ \\
\hline $\mathbf{3}$ & $\begin{array}{c}\text { Instrument } \\
\text { Eligibility }\end{array}$ & $100 \%$ & $88 \%$ & $92 \%$ & $88 \%$ & $92 \%$ \\
\hline & Average & $99 \%$ & $86.6 \%$ & $93.5 \%$ & $88 \%$ & $92 \%$
\end{tabular}




\begin{tabular}{|c|c|c|c|c|c|c|}
\hline & $\begin{array}{l}\text { implementation of } \\
\text { the test }\end{array}$ & & & & & \\
\hline 15 & $\begin{array}{l}\text { The effectiveness } \\
\text { of the use of test } \\
\text { officers }\end{array}$ & 5 & 5 & 5 & 5 & 5 \\
\hline 16 & $\begin{array}{l}\text { Effectiveness of } \\
\text { audio-visual } \\
\text { media guidelines }\end{array}$ & 5 & 5 & 5 & 4 & 5 \\
\hline 17 & $\begin{array}{l}\text { The effectiveness } \\
\text { of the entire test } \\
\text { execution flow }\end{array}$ & 5 & 5 & 3 & 4 & 4 \\
\hline 18 & $\begin{array}{l}\text { The novelty of the } \\
\text { test instrument }\end{array}$ & 5 & 5 & 5 & 4 & 4 \\
\hline 19 & $\begin{array}{l}\text { Ease of } \\
\text { understanding the } \\
\text { guidelines in } \\
\text { terms of sound } \\
\text { audio-visual } \\
\text { media }\end{array}$ & 5 & 4 & 5 & 4 & 5 \\
\hline 20 & $\begin{array}{l}\text { Ease of } \\
\text { understanding the } \\
\text { guidelines for } \\
\text { writing running } \\
\text { audio-visual } \\
\text { media }\end{array}$ & 5 & 5 & 5 & 5 & 5 \\
\hline 21 & $\begin{array}{l}\text { The suitability of } \\
\text { the demonstration } \\
\text { movement with } \\
\text { the basic } \\
\text { techniques of } \\
\text { table tennis }\end{array}$ & 5 & 3 & 2 & 5 & 4 \\
\hline 22 & $\begin{array}{l}\text { Ease of } \\
\text { understanding the } \\
\text { scale of values on } \\
\text { tables and audio- } \\
\text { visual media } \\
\text { sounds }\end{array}$ & 5 & 4 & 5 & 5 & 4 \\
\hline 23 & $\begin{array}{l}\text { The novelty of the } \\
\text { whole set of hand } \\
\text { eye coordination } \\
\text { test instruments }\end{array}$ & 5 & 5 & 5 & 4 & 5 \\
\hline
\end{tabular}

Based on the results of research on filling out questionnaires by experts, the results of content validity using the AIken validity test are described as follows:

Table 4. Aiken Content Validation Results

\begin{tabular}{rccc}
\multicolumn{4}{c}{ Table 4. Aiken Content } \\
\hline No & Indicator & V & Note: \\
\hline $\mathbf{1}$ & Suitability & 0.88 & Very Valid \\
\hline $\mathbf{2}$ & Convenience & 0.9 & Very Valid \\
\hline $\mathbf{3}$ & Guidelines Eligibility & 0.87 & Very Valid \\
\hline \multicolumn{2}{c}{ Total rating average } & 0.883 & Very Valid \\
\hline
\end{tabular}
table tennis for analysis of specific abilities, namely coordination. the eye of the hand which refers to one of the basic techniques of table tennis, namely the stroke technique. This is in accordance with the results of research belonging to [13] that this eye-hand coordination is one of the right ways to identify the basic skills of playing in table tennis because the main focus of the game of table tennis is on arm skills and the focus of the sense of sight [14]. The eye-hand coordination component in table tennis is needed to improve the ability to control the ball, agility, speed and reaction to the ball according to the specifications of the branch.[14],[15]

The results of research and development in the form of an eye-hand coordination test instrument in table tennis games for PJKR FIK UNY students have 
advantages: (1) this eye-hand coordination test instrument can be used as a measuring instrument for initial abilities in table tennis games. (2) this instrument can also be used by lecturers to analyze the basic abilities of playing table tennis to divide students into good or poor abilities as a determination of various learning approaches according to the needs of students' abilities. (3) this test instrument can be used at the beginning or before the table tennis game lectures collectively in the table tennis hall or independently during an emergency such as today, namely during the online learning or Distance Learning (PJJ) period because there are written test guide products in the form of books and audio-visual media in the form of video tutorials that have been uploaded on social media Youtube. The benefits of implementing technology-based learning media are right on target so that the learning objectives of physical education in terms of motor skills are more easily achieved [16],[17],[18]. Identifying capabilities at the beginning of the activity is the right step as an activity program design so that the implementation and results are right on target [19],[20],[21].

Weaknesses and advantages of a product cannot be avoided in a scientific study. Likewise with the eyehand coordination test instrument that has been developed, some of the weaknesses of this product include: (1) the eye-hand coordination test instrument in the new table tennis game was tested in a limited scope. (2) the eye-hand coordination test instrument in the table tennis game can only be done specifically for the table tennis game, so if it is applied to other types of games that focus on the eyes of the other hand, it is not in accordance with the characteristics of the game

\section{CONCLUSION}

This research and development has produced a product in the form of an eye-hand coordination test instrument in a table tennis game for PJKR FIK UNY students. An overview of the instrument and test guidelines through audio-visual on this instrument can be seen on the youtube page https://www.youtube.com/watch? $\mathrm{v}=\mathrm{mQ81AkaYYKg \&}$ $\mathrm{t}=22 \mathrm{~s}$. The indicators of this eye-hand coordination instrument consist of: standing position, foot placement, throwing technique (push), throwing technique (target accuracy), catching technique (hand position), and success of the throw. The value of the content validity of this instrument is at an average value of 0.883 . Content validation involves five experts consisting of three table tennis experts and two test and measurement experts who have tested the validity of the developed instrument. The level of reliability of the test instrument is 0.89 using a test retest approach and then correlated using the Pearson Product Moment formula.

\section{ACKNOWLEDGMENT}

The author would like to thank UNY for funding this group's research.

\section{REFERENCES}

[1] S. Lenar, F. Artur, S. Ullubi, B. Nailya, Problems and Decisions in the Field of Distance Education, Procedia - Soc. Behav. $\quad$ science. $131 \quad$ (2014) 111-117. https://doi.org/10.1016/j.sbspro.2014.04.088.

[2] MMS de Oliveira, AST Penedo, VS Pereira, Distance education: advantages and disadvantages of the point of view of education and society, Dialogia. (2018) 139-152. https://doi.org/10.5585/dialogia.n29.7661.

[3] Septian Raibowo, Yahya Eko Nopiyanto, Pjok's Teaching and Learning Process During the Covid-19 Pandemic, STAND J. Sport. Teach. Dev. 1 (2020) 112-119. https://doi.org/10.36456/j-stand.v1i2.2774.

[4] RCA Silva, VL de FF e Silva, AP Silva, Distance learning for teaching in physical education, Motriz. Rev. Educ. Fis. 25 (2019) 1-5. https://doi.org/10.1590/s19806574201900010002.

[5] C. Wang, Study on the Reform of Table Tennis Teaching Content and Methods in University, (2016) 1337-1340. https://doi.org/10.2991/ssehr-16.2016.283.

[6] GFD Hariyanto, Guntur Firmansyah HISTORY, TECHNIQUES \& VARIATIONS OF PINGPONG EXERCISE (TABLE TENNIS), 2020.

[7] JM Picabea, J. Cámara, J. Yanci, Physical fitness profiling of national category table tennis players: Implication for health and performance, Int. J. Environ. res. Public Health. 18 (2021). https://doi.org/10.3390/ijerph18179362.

[8] S. Limoochi, A survey of table tennis coaches' opinions of some criteria in talent identification, Eur. J. Sport. Exerc. $\begin{array}{llll}\text { science. } & 2 & \text { (2012) }\end{array}$ https://www.scholarsresearchlibrary.com/articles/a-survey-oftable-tennis-coaches-opinions-of-some-criteria-in-talentidentification.pdf.

[9] J. Baker, S. Cobley, J. Schorer, Talent Identification and Development in Sport, Talent Identification. Dev. Sport. 7 (2013) 177-180. https://doi.org/10.4324/9780203850312.

[10] Y. KUSDINAR, AG ABDUlLAH, A. MA'MUN, A. RUSDIANA, Revisiting sports talent identification: A meta analysis, J. Eng. science. Technol. 16 (2021) 1258-1272.

[11] AMN Pasaribu, Sports Tests and Measurements, 2015.

[12] SN Kane, A. Mishra, AK Dutta, Preface: International Conference on Recent Trends in Physics (ICRTP 2016), J. Phys. conf. Ser. 755 (2016). https://doi.org/10.1088/17426596/755/1/011001.

[13] IR Faber, FGJ Oosterveld, MWG Nijhuis-Van Der Sanden, Does an eye-hand coordination test have added value as part of talent identification in table tennis? A validity and reproducibility study, PLoS One. 9 (2014). https://doi.org/10.1371/journal.pone.0085657.

[14] A. V Lopez, OYS Santelices, Personality characteristics of elite table tennis athletes of the Philippines: basis for a proposed recruitment program, 12th ITTF Sport. science. Congr. (2011) 1-4.

[15] B. Vandorpe, JB Vandendriessche, R. Vaeyens, J. Pion, J. Lefevre, RM Philippaerts, M. Lenoir, The value of a nonsport-specific motor test battery in predicting performance in young female gymnasts, J. Sports Sci . 30 (2012) 497-505. https://doi.org/10.1080/02640414.2012.654399.

[16] DM Ste-Marie, MJ Carter, B. Law, K. Vertes, V. Smith, Selfcontrolled learning benefits: exploring contributions of selfefficacy and intrinsic motivation via path analysis, J. Sports 
Sci. $\quad 34 \quad$ (2016) 1650-1656.

https://doi.org/10.1080/02640414.2015.1130236.

[17] JP Morillo-Baro, RE Reigal, A. Hernández-Mendo, Analysis del ataque posicional de bolamano playa masculino y femenino mediaante coordenadas polares, RICYDE Rev. int. Ciencias Del Deport. 11 (2015) 226-244. https://doi.org/10.5232/ricyde.

[18] F. Potdevin, O. Vors, A. Huchez, M. Lamour, K. Davids, C. Schnitzler, How can video feedback be used in physical education to support novice learning in gymnastics? Effects on motor learning, self-assessment and motivation, Phys. Educ. Pedagogical Sports. 23 (2018) 559-574. https://doi.org/10.1080/17408989.2018.1485138.

[19] SN Yasin, A. Ma'mun, A. Rusdiana, AG Abdullah, L. Nur, The talent identification of Kayak athletes: A research-based on analytic hierarchy process, Int. J. Hum. Mov. Sport. $\begin{array}{llll}\text { science. } & 8 & (2020) & 395-402 .\end{array}$ https://doi.org/10.13189/saj.2020.080611.

[20] K. Till, BL Jones, S. Cobley, D. Morley, J. O'Hara, C. Chapman, C. Cooke, CB Beggs, Identifying talent in youth sport: A novel methodology using higher-dimensional $\begin{array}{lllll}\text { analysis, PLoS One. } 11 & \text { (2016) 1-18. }\end{array}$ https://doi.org/10.1371/journal.pone.0155047.

[21] JI Alfonso Mantilla, J. Martínez Santa, OC Vargas, Kinesiogenómica: Una Nueva Perspectiva De Investigación En Fisioterapia, Mov. Cientifico. 10 (2016) 78-86. https://doi.org/10.33881/2011-7191.mct.10107. 